\title{
Letter to the Editor Regarding "The Challenges of Switching Therapies in an Evolving Multiple Biosimilars Landscape: A Narrative Review of Current Evidence"
}

\author{
Barbara Finck (D) · Robert B. Geller · Paul Walden
}

\section{Key Summary Points}

The recent review from Feagan and colleagues neglected to mention several key factors regarding biosimilar use and switching

Multiple switching scenarios apply mostly to chronic-use biologics and are less common with acute-use biologics

Any change in the production process of a reference biologic or biosimilar may affect the clinical activity, efficacy, safety, and/ or immunogenicity of the product

Biosimilars can offer significant cost savings and expand access to critical therapeutic treatments

\section{Dear Editor,}

We read the article by Feagan and colleagues discussing potential challenges of biologic switching with considerable interest [1]. Although we agree with Feagan et al. that highquality clinical and postmarketing studies should be conducted to improve our understanding of potential switching effects, we

B. Finck $(\bowtie)$ - R. B. Geller · P. Walden Coherus BioSciences, Redwood City, CA, USA e-mail: bfinck@coherus.com believe that several additional factors should be considered when discussing biosimilar use and switching.

The multiple switching scenarios discussed by Feagan et al. mostly apply to long-term biologic use, generally in the setting of chronic diseases. However, multiple switches are much less common when biologics are used for a shorter, finite time period. The question of acute-use versus chronic-use biosimilars is highly relevant; 13 of the 28 currently approved biosimilars in the USA are used primarily in acute disease settings, such as in oncology care with biosimilars of the originator biologics bevacizumab, filgrastim, pegfilgrastim, and trastuzumab [2]. The situation is similar in the European Union: 30 of 60 approved biosimilars are commonly used in acute disease settings (from the reference biologics bevacizumab, filgrastim, follitropin alfa, pegfilgrastim, somatropin, teriparatide, and trastuzumab) [3].

Studies of biologic or biosimilar switching for acute-use biologics have consistently demonstrated the safety of switching from a reference biologic to a biosimilar [4-8]. As an example, the biologic pegfilgrastim is commonly used as acute supportive care for patients receiving myelosuppressive chemotherapy. In a recent clinical study using a three-period, threesequence crossover design, pegfilgrastim-cbqv was shown to be bioequivalent regardless of treatment sequence or period, and no unexpected safety signals were observed [4]. The 
safety of switching from originator biologics to biosimilars was also highlighted in a recent systematic literature review that examined 90 studies reporting data on single or multiple biologic switches [9]. This review concluded that most of these studies did not show differences in efficacy, safety, or immunogenicity between patients who remained on an originator biologic over time and those patients who switched from an originator to a biosimilar [9], including during multiple-switch scenarios [10-12].

As Feagan and colleagues correctly state, biosimilars by definition are similar but not identical to their originator biologic [13]. Although biosimilars undergo an extensive and robust regulatory process to ensure similarity to the originator product $[14,15]$, small differences in structural components may exist (e.g., posttranslational modifications) that are not clinically meaningful $[13,16,17]$. However, it is important to note that these differences may also be present between different batches of the reference biologic. The production and purification of biologics is a highly complex process, and batch effects or manufacturing changes (e.g., changes in raw materials, changes in equipment, changes due to upscaling production) can lead to variability in the efficacy, safety, and immunogenicity of reference biologics over time [18-20]. Although the regulatory requirements governing the evaluation of biosimilarity and those governing manufacturing changes differ, these processes share the same goal: to ensure consistent and predictable safety and efficacy of the biologic. As with the development of biosimilars, comparability exercises related to manufacturing changes commonly include physicochemical and biological characterization and may include animal or clinical studies, if necessary. However, the evaluation of a biosimilar is far more extensive, requiring full pharmacokinetic, functional, and immunogenic evaluation, and commonly requiring clinical studies as well $[13,14]$.

In their article, Feagan et al. also did not mention several significant benefits to patients and the healthcare system provided by biosimilars. Over the past decades, biologics have become cornerstones in the clinical management of numerous diseases. However, reference biologics are associated with significant costs and represent a disproportionally large fraction of net drug spending $[21,22]$. Biosimilars are less expensive than the originator product, or at least stimulate price competition in the field of biologics, and offer significant cost savings to individual patients and the healthcare system [23-25]. In addition, biosimilars have the potential to increase accessibility for patients and expand access to critical therapeutic treatments at the national and global level [25-27].

In conclusion, it is critical to distinguish between chronic and acute disease settings when discussing potential risks of biologic/ biosimilar switching scenarios. It is also important to recognize that minor changes in efficacy, safety, and immunogenicity of any biologic drug may occur over time, and these concerns are relevant for reference biologics as well as biosimilars. Finally, while further research is certainly valuable to improve our understanding of potential switching effects, we feel strongly that the benefits of biosimilarsincreased competition, lower drug prices, and broader patient access-should not be overlooked.

\section{ACKNOWLEDGEMENTS}

Funding. Coherus BioSciences (Redwood City, CA, USA) funded this letter, was involved in the collection and interpretation of the data, and in the writing, review, and approval of the publication.

Authorship. All named authors meet the International Committee of Medical Journal Editors (ICMJE) criteria for authorship for this article, take responsibility for the integrity of the work as a whole, and have given their approval for this version to be published.

Authors' Contributions. Barbara Finck, Robert B. Geller and Paul Walden had the idea for the article and critically revised the work. 
Medical Writing and Editorial Assistance. Medical writing assistance was provided by Stacie Dilks, PhD, of ApotheCom (San Francisco, CA, USA) and funded by Coherus BioSciences (Redwood City, CA, USA).

Disclosures. Barbara Finck, Robert B. Geller, and Paul Walden are employees of Coherus BioSciences (Redwood City, CA, USA).

Compliance With Ethics Guidelines. This article is based on previously conducted studies and does not contain any new studies with human participants or animals performed by any of the authors.

Data Availability. Data sharing is not applicable to this article as no datasets were generated or analyzed during the current study.

Open Access. This article is licensed under a Creative Commons Attribution-NonCommercial 4.0 International License, which permits any non-commercial use, sharing, adaptation, distribution and reproduction in any medium or format, as long as you give appropriate credit to the original author(s) and the source, provide a link to the Creative Commons licence, and indicate if changes were made. The images or other third party material in this article are included in the article's Creative Commons licence, unless indicated otherwise in a credit line to the material. If material is not included in the article's Creative Commons licence and your intended use is not permitted by statutory regulation or exceeds the permitted use, you will need to obtain permission directly from the copyright holder. To view a copy of this licence, visit http://creativecommons.org/licenses/by$\mathrm{nc} / 4.0 /$.

\section{REFERENCES}

1. Feagan BG, Marabani M, Wu JJ, Faccin F, Spronk C, Castañeda-Hernández G. The challenges of switching therapies in an evolving multiple biosimilars landscape: a narrative review of current evidence. Adv Ther. 2020;37(11):4491-518.
2. Us Food And Drug Administration. Biosimilar Product Information. https://www.Fda.Gov/Drugs/ Biosimilars/Biosimilar-Product-Information. Accessed 1 Dec, 2020.

3. European Medicines Agency. Biosimilar Medicines. https://www.Ema.Europa.Eu/En/Medicines/Field_ Ema_Web_Categories\%253aname_Field/Human/ Ema_Group_Types/Ema_Medicine/Field_Ema_ Med_Status/Authorised-36/Ema_Medicine_Types/ Field_Ema_Med_Biosimilar/Search_Api_ Aggregation_Ema_Medicine_Types/Field_Ema_ Med_Biosimilar. Accessed 1 Dec, 2020.

4. Finck B, Tang H, Civoli F, Hodge J, O'Kelly H, Vexler V. Pharmacokinetic and pharmacodynamic equivalence of pegfilgrastim-cbqv and pegfilgrastim in healthy subjects. Adv Ther. 2020;37(10): 4291-4307.

5. Parker T, Britton L, Willis C, et al. A Retrospective analysis of the clinical and financial outcomes of converting patients from originator remicade to an infliximab biosimilar. Poster presented at: Nexus2020 Virtual; Week Of October 19, 2020.

6. Moots R, Azevedo V, Coindreau Jl, et al. Switching between reference biologics and biosimilars for the treatment of rheumatology, gastroenterology, and dermatology inflammatory conditions: considerations for the clinician. Curr Rheumatol Rep. 2017;19(6):37.

7. Pernes T, Patel M, Kahn N. The safety of switching from originator infliximab or biosimilar Ct-P13 To $\mathrm{Sb} 2$ among a nationwide cohort of inflammatory bowel disease patients. ACG 2020; Virtual2020.

8. Jørgensen KK, Olsen IC, Goll GL, et al. Switching from originator infliximab to biosimilar Ct-P13 compared with maintained treatment with originator infliximab (Nor-Switch): a 52-week, randomised, double-blind, non-inferiority trial. Lancet. 2017;389(10086):2304-16.

9. Cohen HP, Blauvelt A, Rifkin RM, Danese S, Gokhale SB, Woollett G. Switching reference medicines to biosimilars: a systematic literature review of clinical outcomes. Drugs. 2018;78(4): 463-78.

10. Blackwell K, Semiglazov V, Krasnozhon D, et al. Comparison of Ep2006, a filgrastim biosimilar, to the reference: a phase iii, randomized, double-blind clinical study in the prevention of severe neutropenia in patients with breast cancer receiving myelosuppressive chemotherapy. Ann Oncol. 2015;26(9):1948-53.

11. Griffiths C, Thaçi D, Gerdes S, et al. The EGALITY study: a confirmatory, randomized, double-blind study comparing the efficacy, safety and 
immunogenicity of Gp2015, a proposed etanercept biosimilar, vs. the originator product in patients with moderate-to-severe chronic plaque-type psoriasis. Br J Dermatol. 2017;176(4):928-38.

12. Blauvelt A, Lacour JP, Fowler Jf Jr, et al. Phase III randomized study of the proposed adalimumab biosimilar GP2017 in psoriasis: impact of multiple switches. Br J Dermatol. 2018;179(3):623-631.

13. US Food And Drug Administration. Guidance for Industry. Scientific Considerations in Demonstrating Biosimilarity to a Reference Product. https:// www.Fda.Gov/Media/82647/Download. Published April 2015. Accessed 1 Dec, 2020.

14. Wolff-Holz E, Tiitso K, Vleminckx C, Weise M. Evolution of the EU biosimilar framework: past and future. BioDrugs. 2019;33(6):621-34.

15. Verrill M, Declerck P, Loibl S, Lee J, Cortes J. The rise of oncology biosimilars: from process to promise. Future Oncol. 2019;15(28):3255-65.

16. European Medicines Agency. Guideline on Similar Biological Medicinal Products Containing Biotechnology-Derived Proteins as Active Substance: NonClinical and Clinical Issues. https://www.Ema. Europa.Eu/En/Documents/Scientific-Guideline/ Guideline-Similar-Biological-Medicinal-ProductsContaining-Biotechnology-Derived-ProteinsActive_En-2.Pdf. Published December 18, 2014. Accessed 1 Dec, 2020.

17. European Medicines Agency. Biosimilars in the EU. Information Guide for Healthcare Professionals. 2019. https://www.Ema.Europa.Eu/En/Documents/ Leaflet/Biosimilars-Eu-Information-Guide-Health care-Professionals_En.Pdf. Accessed 1 Dec, 2020.

18. Vezér B, Buzás Z, Sebeszta M, Zrubka Z. Authorized manufacturing changes for therapeutic monoclonal antibodies (mAbs) in European Public Assessment Report (EPAR) documents. Curr Med Res Opin. 2016;32(5):829-34.

19. Declerck P, Farouk-Rezk M, Rudd PM. Biosimilarity versus manufacturing change: two distinct concepts. Pharm Res. 2016;33(2):261-8.
20. Kim S, Song J, Park S, et al. Drifts in ADCC-related quality attributes of Herceptin ${ }^{\circ}$ : impact on development of a trastuzumab biosimilar. MAbs. 2017;9(4):704-14.

21. Feagan B. Benefits, concerns, and future directions of biosimilars in inflammatory bowel disease. Gastroenterol Hepatol. 2017;13(12):745-7.

22. Mulcahy AW, Hlavka JP, Case Sr. Biosimilar cost savings in the United States: initial experience and future potential. Rand Health Q. 2018;7(4):3

23. Webster J, Smith RE, Wieland D, Verniero J, Scott JA. Cost savings of biosimilar pegfilgrastim in a Medicare OCM population. J Clin Oncol. 2020;38(suppl 15).

24. Hübel K, Kron F, Lux MP. Biosimilars in oncology: effects on economy and therapeutic innovations. Eur J Cancer. 2020;139:10-9.

25. MacDonald K, McBride A, Alrawashdh N, Abraham I. Cost-efficiency and expanded access of prophylaxis for chemotherapy-induced (febrile) neutropenia: economic simulation analysis for the US of conversion from reference pegfilgrastim to biosimilar pegfilgrastim-cbqv. J Med Econ. 2020:1-11.

26. McBride A, MacDonald K, Abraham I. Simulation modeling of cost-savings from conversion of pegfilgrastim to biosimilar pegfilgrastim-cbqv for the prophylaxis of chemotherapy-induced (febrile) neutropenia (CIN/FN) and expanded access to biosimilar prophylaxis. J Clin Oncol. 2020;38(suppl 15).

27. McBride A, MacDonald K, Abraham I. Simulation modeling of budget-neutral expanded access to antineoplastic therapy from cost-savings derived from conversion to biosimilar pegfilgrastim-cbqv for the prophylaxis of chemotherapy-induced (febrile) neutropenia $(\mathrm{CIN} / \mathrm{FN})$ in early-stage breast cancer. J Clin Oncol. 2020;38(suppl 15). 